\title{
Response of the large-scale subglacial drainage system of Northeast Greenland to surface elevation changes
}

\author{
N. B. Karlsson and D. Dahl-Jensen \\ Centre for Ice and Climate, The Niels Bohr Institute, University of Copenhagen, Denmark \\ Correspondence to: N. B. Karlsson (nbkarlsson@nbi.ku.dk) \\ Received: 17 December 2014 - Published in The Cryosphere Discuss.: 29 January 2015 \\ Revised: 21 June 2015 - Accepted: 6 July 2015 - Published: 6 August 2015
}

\begin{abstract}
The influence of subglacial water on the dynamics of ice flow has been the object of increasing interest in the past decade. In this study we focus on large-scale, longterm changes in surface elevation over Northeast Greenland and the corresponding changes in subglacial water routeways. Our results show that over timescales ranging from decades to millennia the area may experience redistribution of and fluctuation in subglacial water outflux under the main glacier outlets. The fluctuations in subglacial water routing occur even in the absence of external forcing. Based on these results we conclude that changes in the subglacial water routeways are an intrinsic part of the drainage basin dynamics, where the subglacial system is likely always in a transient state. The results also imply that fluctuations at the margins observed at present might originate from changes several hundred kilometres upstream. Since surface elevation changes may propagate upstream over timescales much longer than the observational period, the cause of the fluctuations may not be present in current observational records.
\end{abstract}

\section{Introduction}

The loss of mass from the Greenland Ice Sheet (GrIS) and its corresponding contribution to sea-level rise is by now well documented (e.g. Vaughan et al., 2013; Hanna et al., 2013). Hence, recent years have seen an increasing interest in the response of different regions of the GrIS to climatic forcings (e.g. van den Broeke et al., 2009; Bolch et al., 2013). While the outlet glaciers in southern Greenland have been speeding up during the past decade (Bevan et al., 2012), the glaciers in the northeast have until recently been considered relatively stable, partly due to the presence of sea ice and/or small ice shelves (Joughin et al., 2010).

In the northeastern drainage basin, the Northeast Greenland Ice Stream (NEGIS) dominates the transport of ice to the sea. NEGIS was discovered only a few decades ago when SAR (synthetic aperture radar) imagery revealed the presence of a fast-flow feature on the surface of the GrIS (Fahnestock et al., 1993). In comparison to other Greenlandic ice streams NEGIS is very long (more than $600 \mathrm{~km}$ ), and it reaches velocities of $20 \mathrm{~m} \mathrm{yr}^{-1}$ less than $150 \mathrm{~km}$ from the ice divide (Joughin et al., 2010). At the margin, NEGIS splits into three outlets (Fig. 1): Nioghalvfjerdsbræ (also at times referred to as $79 \mathrm{~N}$ Glacier), Zachariae Isstrøm and Storstrømmen. A study by Joughin et al. (2010) reported that, while Zachariae Isstrøm is speeding up, Nioghalvfjerdsbræ shows only a small speed-up and Storstrømmen is slowing down slightly. Khan et al. (2014) also found that NEGIS was stable in the past, but they report that the sector experienced rapid dynamic thinning at some point between 2003 and 2006. The authors link this speed-up to increasing summer temperatures and decreasing sea-ice concentration.

The three main outlets of NEGIS drain more than $20 \%$ of the GrIS (by area; Rignot and Kanagaratnam, 2006); it is therefore of considerable interest to understand the processes governing its ice flow. Generally, ice streams are triggered and modulated by a range of different processes that operate on varying temporal and spatial timescales (Winsborrow et al., 2010). NEGIS, for example, is thought to be initiated by an anomalously high geothermal heat flux close to the ice divide (Fahnestock et al., 1993). Studies indicate that the flow of the ice stream is "streaming" with very low basal shear stresses (Joughin et al., 2001). Thus, most of the ice flow in the main part of NEGIS is thought to be due to sliding 
over the subglacial topography facilitated by subglacial water rather than internal deformation (Joughin et al., 2001). This has also been confirmed by analyses of radio-echo sounding data retrieved from the central ice-stream trunk (Keisling et al., 2014). It is well known that liquid water at the ice bed has the potential to modify and even control the iceflow dynamics; this happens both directly by decreasing the friction between the ice and the bed, and by modifying the subglacial sediment (e.g. Alley et al., 1986; Zwally et al., 2002; Clarke, 2005). Studies of subglacial processes confirm the importance of liquid water for ice-stream behaviour (e.g. Anandakrishnan and Alley, 1997; Fahnestock et al., 2001), and recent modelling efforts have begun to address this (e.g. Bougamont et al., 2011; de Fleurian et al., 2014). The coupling between ice flow and subglacial processes is, however, complicated and not easily incorporated into ice-sheet models. This is partly because the subglacial system may exhibit different characteristics, ranging from networks of cavities and efficient tunnel-like systems to inefficient conduits, thin water films and water flow in sediments (e.g. Gulley et al., 2009; Schoof, 2010; Iverson and Petersen, 2011).

One process that may alter ice-stream behaviour over short timescales (centennial timescales or less) is the routing of subglacial meltwater caused by variations in the subglacial hydrological system. Variations such as these are thought to have triggered significant changes in the slowing-down or speeding-up of Antarctic ice streams such as the Siple Coast ice streams (Anandakrishnan and Alley, 1997) and the Rutford Ice Stream (Vaughan et al., 2008). In fact, a study by Wright et al. (2008) found that the subglacial system in a large part of East Antarctica is potentially sensitive to even small changes in ice-sheet elevation.

In contrast, changes in ice flow directly related to the subglacial system have not yet been documented for Greenland. This is in spite of an active ice-stream drainage system (Joughin et al., 2010) and few topographic constraints on most of the ice streams (Bamber et al., 2013a). This is even more surprising since it is well known that liquid water is widespread under large parts of the Greenland Ice Sheet; this has been testified by observations of subglacial water at ice core drill sites (Dahl-Jensen et al., 2003) and from radioecho sounding surveys (Gogineni et al., 2001; Oswald and Gogineni, 2008), and it is supported by results from largescale ice-sheet modelling (Greve and Hutter, 1995; Seroussi et al., 2013).

Recent geophysical surveys on NEGIS have found evidence of basal water along the shear margin, and the study concludes that NEGIS is controlled by subglacial water routing rather than bed topography and that rapid shifts in ice dynamics are possible (Christianson et al., 2014). Here, we demonstrate that changes in surface elevation of the Northeast Greenland basin over centuries or less may change the subglacial water routeways and potentially influence the ice flow of the area. We use a simple model approach and are therefore not aiming to, or indeed capable of, capturing the present-day variations and dynamics of the region, since this variability is coupled to several complex processes not included in our model (cf. Larour et al., 2014). Rather, we focus on the sensitivity of the drainage basin to realistic fluctuations in surface elevation over timescales of decades to millennia and the corresponding change in hydropotential. In this case, the use of a simple model is justified because it can be run over millennial timescales and still provide a realistic estimate of the ice-flow behaviour.

\section{Methods}

We use a simple two-dimensional (2-D) map-plane ice-flow model to model the change in surface elevation over time in response to incremental increases in basal sliding. The resulting time-dependent surface elevation is used to calculate the hydropotential, in order to investigate the changes in outflux of subglacial water at the margin over time. We force the model with a mass balance field and prescribed calving rates. Data input into the model are surface and bed elevation from Bamber et al. (2013a) regridded to $5 \mathrm{~km}$ (northeastern drainage basin) and $10 \mathrm{~km}$ (GrIS, used in the spin-up run), and present-day modelled mass balance from Ettema et al. (2009).

\subsection{Ice-flow model}

The ice-flow model is a 2-D-plane model that calculates the changes in ice surface elevation in response to gravity and mass balance. It is vertically integrated and based on the shallow-ice approximation using a number of simplifying assumptions. Firstly, we assume that the basal shear stress $\tau_{\mathrm{b}}$ is equal to the driving stress $\tau_{\mathrm{d}}$ :

$\tau_{\mathrm{b}}=\tau_{\mathrm{d}}=\rho g H \nabla s$,

where $H$ is ice thickness, $s$ is surface elevation, $g$ is the gravitational constant and $\rho$ is the density. This assumption entails that stress components are neglected that may be important for an ice stream such as NEGIS. We return to this assumption and the impact it may have on our results in the Discussion section. We then relate the stress to the strain rate using Glen's law, $\dot{\epsilon}_{i j}=A \tau_{i j}^{n}$, and set the flow law exponent $n$ equal to 3 . The creep parameter $A$ depends exponentially on the temperature of the ice, as well as on water content, the hydrostatic pressure, impurity content and the ice rheology (Cuffey and Paterson, 2010).

Secondly, we assume that the (vertically averaged) horizontal velocity vector $\bar{u}$ is composed of two parts: a term caused by the internal deformation of the ice, $\bar{u}_{\mathrm{d}}$, and a term derived from sliding over the bed, $u_{\mathrm{s}}$; thus $\bar{u}=\bar{u}_{\mathrm{d}}+u_{\mathrm{s}}$. The deformational velocity takes the well-known form $\bar{u}_{\mathrm{d}}=k_{\mathrm{d}} H \tau_{\mathrm{b}}^{n}$, where $k_{\mathrm{d}}$ is related to the creep parameter $A$ and thus also depends on temperature, water content etc. The sliding velocity $u_{\mathrm{s}}$ is approximated using a non-linear, "Weertman-type" slid- 

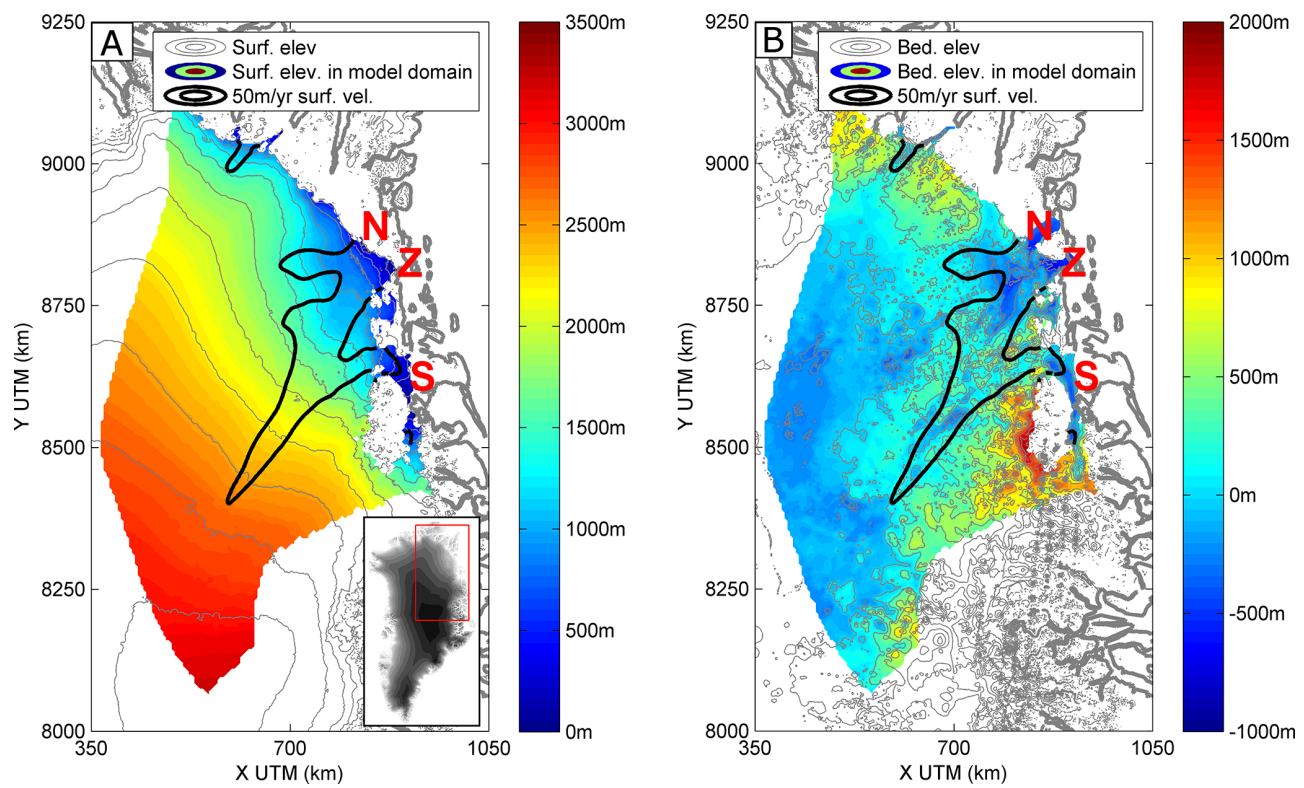

Figure 1. Surface (a) and bed elevation (b) (Bamber et al., 2013a) in grey contours. N stands for Nioghalvfjerdsbræ, Z for Zachariae Isstrøm and $\mathrm{S}$ for Storstrømmen. The $5 \mathrm{~km}$ model domain for the Northeast Greenland drainage basin is shown in colours, and the contour for the $50 \mathrm{~m} \mathrm{yr}^{-1}$ surface velocity (from Joughin et al., 2010) is indicated with thick, black lines.

ing law (Weertman, 1957): $u_{\mathrm{s}} \propto \frac{\tau_{\mathrm{b}}^{n}}{\rho g H-P}$; in the following we assume that the basal water pressure $P$ is a constant fraction of the ice load and thus

$u_{\mathrm{s}}=k_{\mathrm{s}} \frac{\tau_{\mathrm{b}}^{n}}{H}$.

Combining the equations above leads to an expression for the surface velocity of the form (Budd et al., 1979; Oerlemans, 2001)

$\bar{u}=k_{\mathrm{d}} H \tau_{\mathrm{b}}^{n}+k_{\mathrm{s}} \frac{\tau_{\mathrm{b}}^{n}}{H}$.

We use the relation above to solve for the ice thickness as a function of time by considering ice flow as a diffusion equation,

$\frac{\partial H}{\partial t}=\nabla(\bar{u} H)+\dot{b}_{i}=\nabla(D \nabla s)+\dot{b}_{i}$,

where $\dot{b}_{i}$ is the mass balance. Combining Eq. (1) with Eqs. (3-4) shows that $D$ is related to the deformation and sliding mechanisms (e.g. Oerlemans, 2001):

$D=(\rho g)^{n} H^{n}(\nabla s)^{n-1}\left(k_{\mathrm{d}} H^{2}+k_{\mathrm{s}}\right)=D_{\mathrm{d}}+D_{\mathrm{s}}$.

Finally, we assume that the bedrock is unchanged in time and thus that any changes in surface elevation directly reflect changes in ice thickness, $\partial H / \partial t=\partial s / \partial t$, further ignoring firn densification processes. Equation (4) is solved on a staggered grid using a Crank-Nicholson, second-order, finitedifference scheme that is centralised except at the margins where upstream differencing is applied. We further note that the solution on a staggered grid introduces a smoothing that means that the model is not inherently mass-conserving.

\subsubsection{Margin control}

On the spatial and temporal scales of our ice-flow model, margin dynamics cannot be expected to be accurately captured. We therefore introduce a discharge scheme to prevent unphysical build-up of mass at the margins by removing ice at every time step. We adopt the following parameterisation from Calov et al. (2015):

$d=c_{0} \frac{H_{0}}{l^{3}}$,

where $d$ is the discharge, $H_{0}$ is the ice thickness at the start of the model run (present-day ice thickness) and $l$ is the distance to the nearest ocean grid cell. We apply this discharge correction to all cells that are within $10 \mathrm{~km}$ of the ice sheet margin. The constant $c_{0}$ is then scaled such that the total discharge out of the drainage basin is twice the size of the ablation. Especially at the start of the model runs, the upstream differencing means that there is an unphysical build-up of mass at the margin. To check this, we calculate the balance velocity at each time step and remove grid cells where the change in ice thickness exceeds the balance influx by more than $500 \%$. The grid cells are then replaced by the average ice thickness of the neighbouring cells.

\subsubsection{Basal sliding}

The basal conditions of the system are determined by the value of the sliding coefficient $k_{\mathrm{s}}$. We estimate the sliding coefficient $k_{\mathrm{s}}$ and the deformational coefficient $k_{\mathrm{d}}$ using a simple inverse approach. First, the model domain is divided 
into three areas based on observed surface velocities (from Joughin et al., 2010): (1) areas where the velocity is less than $5 \mathrm{~m} \mathrm{yr}^{-1}$, (2) areas with velocities between 5 and $100 \mathrm{~m} \mathrm{yr}^{-1}$ and (3) areas where the velocities exceed $100 \mathrm{~m} \mathrm{yr}^{-1}$. The division is based on the assumption that ice flowing at less than $5 \mathrm{~m} \mathrm{yr}^{-1}$ is moving primarily by deformation, while ice flowing above $100 \mathrm{~m} \mathrm{yr}^{-1}$ is mainly due to plug flow (cf. Joughin et al., 2001). This division is used as a weighting scheme for calculating the misfits between observed velocities $v_{\text {obs }}$ and calculated velocities. The inversions are performed on the $1 \mathrm{~km}$ resolution topography data and subsequently regridded.

The deformational coefficient $k_{\mathrm{d}}$ is assumed to be constant in the entire model domain and is calculated by minimising the misfit between observed and calculated deformational velocity $\bar{u}_{\mathrm{d}}$, while neglecting the misfits in area 3 , where ice flow is dominated by sliding. The same approach is then applied in order to obtain a value for $k_{\mathrm{s}}$, but now it is the misfit between $v_{\mathrm{obs}}$ and $\bar{u}=\bar{u}_{\mathrm{d}}+u_{\mathrm{s}}$ that is assessed, while $k_{\mathrm{s}}$ is allowed to vary in each grid cell. The weighting scheme is reversed such that the fast-flow areas (area 3) are weighted more than the intermediate-flow areas (area 2), while slowflow areas are disregarded. For more information on the inverse method see the appendix.

\subsection{Subglacial water routeways}

The changes in the large-scale subglacial drainage pattern are assessed by considering the changes in the hydropotential. On large spatial scales (i.e. kilometre scale) water under ice sheets can be assumed to follow the gradient of the hydrological pressure potential $\Phi$ defined as (Shreve, 1972)

$\Phi=\rho_{w} g z_{\mathrm{b}}+\rho_{i} g\left(z_{\mathrm{s}}-z_{\mathrm{b}}\right)$,

where $\rho_{w}$ and $\rho_{i}$ are water and ice densities, respectively; $g$ is the gravitational constant; and $z_{\mathrm{s}}, z_{\mathrm{b}}$ are the elevations of ice surface and bed. The steepest down-slope gradient of the potential indicates the routeway of the water assuming that the subglacial water pressure is equal to the ice overburden pressure. Here we disregard smaller-scale features such as the formation of channels and conduits.

From Eq. (7) it can be seen that the surface slope is approximately 10 times more important than the slope of the bed topography, implying that, unless the relief of the subglacial topography is steep, the surface slope controls the water routeways. Thus, to a first order the changes in subglacial drainage pattern is controlled by changes in surface slope.

We calculate the outflux of subglacial water at the fjord outlets using the simple, central difference flux calculation by Budd and Warner (1996), modified to follow the hydropotential instead of surface elevation. This scheme has been shown to be the most suitable for calculating fluxes across profiles since it is consistent for different orientations and resolutions, which is not always a given for routing schemes (Le Brocq et al., 2006). We use the routing scheme to cal- culate the distribution of subglacial water (for a given basal melt configuration, see below) every 100 model years. This allows us to calculate the outflux of subglacial water at the margins of the model domain over time and thereby investigate the changes in outflux.

\subsection{Model runs}

The model run consists of three parts: $20 \mathrm{kyr}$ of initialisation, $20 \mathrm{kyr}$ with increasing basal sliding and a final $10 \mathrm{kyr}$ of no forcing. The initialisation is performed in order to obtain an ice sheet configuration consistent with our numerical scheme. Since we wish to obtain realistic changes in ice surface elevation for changing basal sliding values, we want to start with an initial state dominated primarily by deformation. Once this initial state is obtained, we force the model with stepwise increasing basal sliding values over $20 \mathrm{kyr}$ using the results from the basal sliding inversion scheme. Finally, we let the model run for another $10 \mathrm{kyr}$ without any change in forcing.

The results from the inversion are used to force the model in the second stage of our run not to initialise the model. In this section we elaborate on why we adopted this approach: the sliding coefficient values obtained from the inverse scheme are based on the present-day observed topography. Thus, if the inversion scheme perfectly represents the basal sliding coefficient, we could use the results to initialise the model and obtain a surface topography similar to present day. This surface topography would be in agreement with our numerical scheme without the need for a relaxation time. However, our inversion was performed on a different resolution grid and subsequently regridded. Furthermore, both the ice-flow model and the inversion scheme are approximate solutions to the full stress equations. It is therefore unlikely that the inversion scheme perfectly captures the basal sliding in the entire basin, and the ice-flow model will consequently need a relaxation time in order for the numerical scheme to reflect the surface topography. During this relaxation phase, any change in surface topography could be due to the relaxation and not the response of the ice surface to changes in basal conditions. Thus, it would not be possible to attribute the changes in ice sheet elevation directly to the imposed change in basal condition. This would directly impede our aim of obtaining realistic changes in ice surface elevation for changing basal sliding values.

Accordingly, our model run is as follows: using the present-day surface topography, we do a spin-up run over $20 \mathrm{kyr}$ where the sliding coefficient (cf. Fig. 2) is set to $10^{-11}$ $\mathrm{Pa}^{-3} \mathrm{~m}^{2} \mathrm{yr}^{-1}$ or less. During the spin-up the ice-flow model is run on two grids; a $10 \mathrm{~km}$ grid for the entire GrIS and a $5 \mathrm{~km}$ grid for the model domain encompassing the Northeast Greenland basin (shown in colours in Fig. 1). At every model year the grid cells along the drainage basin boundary are updated with the result from the $10 \mathrm{~km}$ model downscaled to the $5 \mathrm{~km}$ grid by linear interpolation. The drainage basin bound- 
aries are assumed to not shift position over time. In this way, we obtain a simulated steady-state ice sheet whose shape is in agreement with the numerical scheme of our model and not substantially influenced by basal sliding.

We then perform our simulation of changing basal conditions starting from the steady-state ice-sheet configuration obtained from the spin-up. We decouple the nested regional $5 \mathrm{~km}$ model from the $10 \mathrm{~km}$ resolution ice-sheet model, and the surface elevation is now kept constant along the basin boundary. The maximum allowed sliding coefficient value $k_{\mathrm{S}}$ is now increased in small steps every 1000 model years for $20 \mathrm{kyr}$. For the first 1000 model years after the spin-up, all basal sliding coefficient values that exceed $1.25 \times 10^{-11}$ $\mathrm{Pa}^{-3} \mathrm{~m}^{2} \mathrm{yr}^{-1}$ are set to $1.25 \times 10^{-11} \mathrm{~Pa}^{-3} \mathrm{~m}^{2} \mathrm{yr}^{-1}$; after another 1000 years, all values that exceed $1.5 \times 10^{-11}$ $\mathrm{Pa}^{-3} \mathrm{~m}^{2} \mathrm{yr}^{-1}$ are set to $1.5 \times 10^{-11} \mathrm{~Pa}^{-3} \mathrm{~m}^{2} \mathrm{yr}^{-1}$ and so forth. When the basal sliding is increased in the subsequent model run, we can then assume that the corresponding changes in surface elevation directly reflect the response of the model domain to the changes in basal conditions. Finally, after $20 \mathrm{kyr}$ the sliding coefficient is kept constant, and the model is run for another $10 \mathrm{kyr}$. This last stage of the model simulation is what we refer to when we use the term "no external forcing" because no further changes are imposed on the basal conditions, although margin loss and mass balance field are still applied.

\section{Results}

\subsection{Sliding coefficient}

Using a simple inversion technique described in Appendix A, we obtain an estimate of the coefficients $k_{\mathrm{d}}$ and $k_{\mathrm{s}}$. The result of the inversion gives a value of $k_{\mathrm{d}}=2.3 \times$ $10^{-17} \mathrm{yr}^{-1} \mathrm{~Pa}^{-3}$. For comparison, empirical studies by Budd et al. (1979) reported a value of $k_{\mathrm{d}}=6.0 \times 10^{-17} \mathrm{yr}^{-1} \mathrm{~Pa}^{-3}$. This corresponds to creep parameter values of $A=1.82 \times$ $10^{-24} \mathrm{~s}^{-1} \mathrm{~Pa}^{-3}$ and $A=4.75 \times 10^{-24} \mathrm{~s}^{-1} \mathrm{~Pa}^{-3}$, respectively. Considering that our estimate applies to the entire drainage basin and that the creep parameter $A$ varies by orders of magnitude depending on ice temperature (Cuffey and Paterson, 2010), we consider this discrepancy to be within the expected uncertainty of our method. Further, we note that the creep parameter values correspond to ice temperatures between -2 and $0^{\circ} \mathrm{C}$ (Cuffey and Paterson, 2010).

The results from inverting for the sliding coefficient $k_{\mathrm{S}}$ are shown in Fig. 2. Note that the solution has been regridded to $5 \mathrm{~km}$ from the original $1 \mathrm{~km}$ solution (see also above) and smoothed with a running mean to impose a degree of smoothness. Our values are within the range of values typically found in models of subglacial settings and also comparable to laboratory experiments that suggest a value of $k_{\mathrm{s}}=1.8 \times 10^{-12} \mathrm{~Pa}^{-3} \mathrm{~m}^{2} \mathrm{yr}^{-1}$ (Budd et al., 1979). This experimental value has been found to agree well with ob-

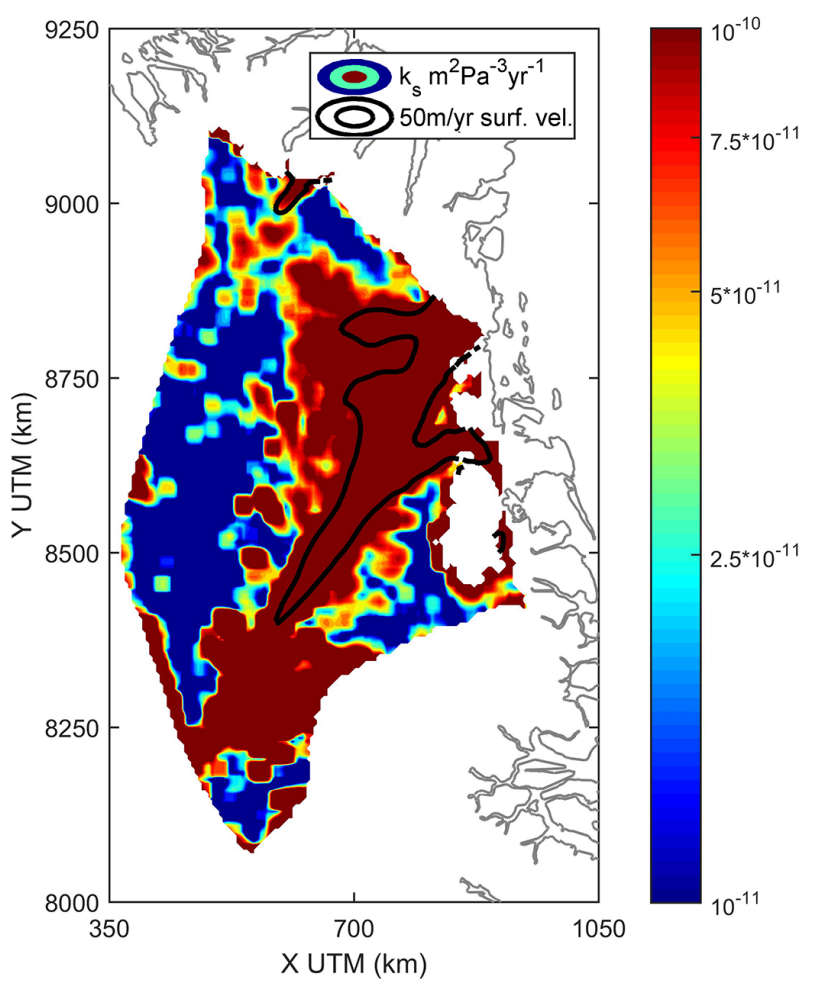

Figure 2. The result of the inversion for the sliding coefficient $k_{\mathrm{S}}$ on a logarithmic scale. The contour for the $50 \mathrm{~m} \mathrm{yr}^{-1}$ surface velocity (from Joughin et al., 2010) is indicated with thick, black lines.

servations from real glaciers (Bindschadler, 1983), although the value is likely very variable for different glacier settings. Even so, our results indicate a high degree of basal sliding. In this experiment the coefficient has been allowed to vary spatially in the model domain to produce the best fit between observed and modelled velocities. It is clear that large parts of the basin have a very high sliding coefficient, notably the fast-flowing areas of NEGIS, indicating high basal velocities. North of NEGIS a large area obtains a low sliding coefficient, indicating that ice deformation is likely more important here than in the ice stream. This pattern is similar to that recovered by previous studies (e.g. Joughin et al., 2001; Schlegel et al., 2013). The area along the ice divide with high basal sliding coefficients is caused by the low surface gradient (leading to an underestimation of modelled velocities) rather than actual large sliding velocities.

\subsection{Changes in ice volume and surface elevation}

In the spin-up run the ice-flow model is initiated with a low value of $k_{\mathrm{S}}\left(k_{\mathrm{s}}=1 \times 10^{-11} \mathrm{~m}^{2} \mathrm{yr}^{-1} \mathrm{~Pa}^{-3}\right)$, and we thus obtain a state where the ice flow in the model domain is not materially influenced by basal sliding. When the model is initiated, there is a drop in ice volume (Fig. 3) as the ice withdraws from the poorly resolved outlets along the margin. The discharge scheme is probably also overestimating the mass loss 


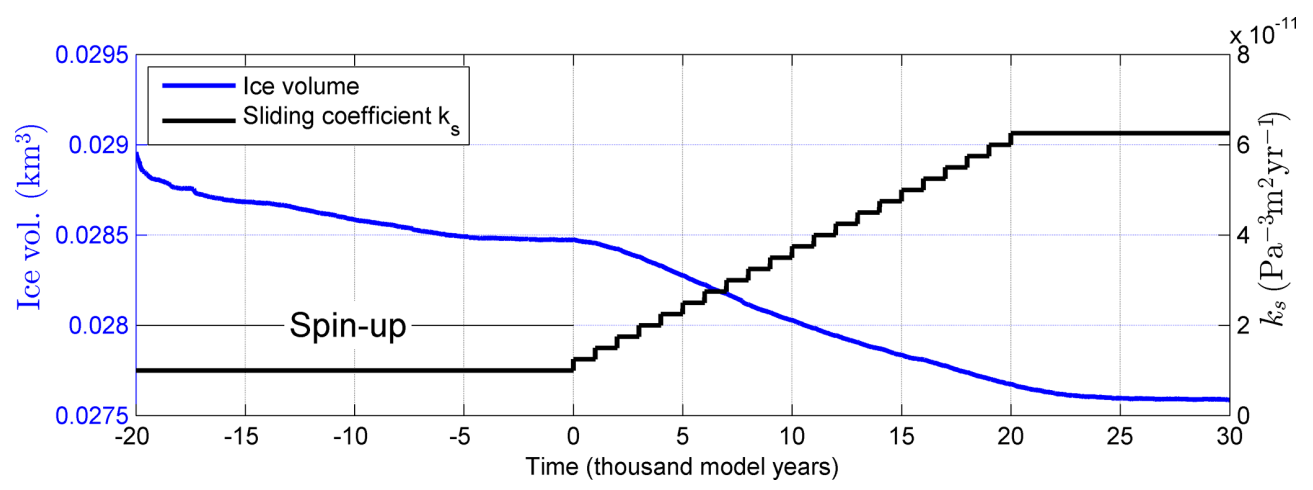

Figure 3. Change in ice volume (blue) of the NE Greenland model domain caused by the change in sliding coefficient (black) for the entire model run.

for some of the margin cells, which further adds to the retreat at the margins. After approximately $17 \mathrm{kyr}$ the ice volume stabilises and after $20 \mathrm{kyr}$ the change in volume is negligible (cf. Fig. 3, blue line). Due to the low sliding coefficient there is a build-up of ice volume in areas where the ice-flow velocities are lower than present day.

The surface elevation along the basin boundaries decreases slightly over the entirety of the spin-up run. This is because the $10 \mathrm{~km}$ model predicts lower elevation along the basin boundaries, leading to a lowering of the grid cells that are interpolated from the $10 \mathrm{~km}$ model onto to the nested $5 \mathrm{~km}$ model. The build-up of ice volume in the central part of the NEGIS naturally corresponds to an increase in surface elevation (cf. Fig. 4). As the maximum allowed sliding coefficient values are increased, the surface elevation decreases and the ice volume decreases correspondingly.

The resulting difference in elevation between present-day topography and the surface elevation after the $20 \mathrm{kyr}$ spinup run and the $30 \mathrm{kyr}$ run is shown in Fig. 4. The number of grid cells with a surface elevation difference larger than $200 \mathrm{~m}$ is less than $7 \%$, and $40 \%$ are within $\pm 100 \mathrm{~m}$ of the present-day elevation. Finally, it should be noted that it was not possible to match the high velocities of the central part of the NEGIS, regardless of the sliding coefficient values. This is probably due to the combined effects from the simplifications in the ice-flow model and the fact that the deformational coefficient is too high in the fast-flow areas, where the ice is likely softer. Thus, our model will always underestimate the ice-flow velocities in the central part of the ice stream.

To test the impact of the margin control algorithm we did an additional model run where the margins were kept constant after the spin-up, and we will refer to this run as the "constant margin run". During the first 20 thousand model years the ice surface is lowering as the basal sliding coefficient is increased. Since the ice margin now is kept at constant thickness this means that the margin is thicker in the constant margin run compared to the initial model run. This thickness difference propagates hundreds of kilometres upstream over time-scales of $10^{3} \mathrm{yr}$. When the basal sliding co- efficient is no longer increased, the difference between the two model runs decrease as the margins thicken in the initial run. Throughout, the differences between the two modelled surfaces are of the order of $10^{1} \mathrm{~m}$ and rarely exceed $20 \mathrm{~m}$. Thus, while it is possible for changes at the margin to propagate upstream in our model, the changes are smaller than those observed for the changes in basal sliding. This implies that our margin control scheme is less important compared to the induced changes in basal sliding.

\subsection{Subglacial water outflux}

The drainage pattern (Fig. 5b) and resulting outflux of subglacial water (Fig. 6) have been calculated using two scenarios: (1) assuming that the entire bed is at pressure melting point (blue lines in Figs. 5 and 6), as suggested by modelling studies (e.g. Greve, 2005; Seroussi et al., 2013), or (2) assuming that melting only occurs in localised areas (magenta lines in Figs. 5 and 6) as indicated by radio-echo sounding data (Oswald and Gogineni, 2012). In both cases we assume a melt rate of $5 \mathrm{~mm} \mathrm{yr}^{-1}$ from each melting grid cell. This is based on values of basal melt rates of $5 \mathrm{~mm} \mathrm{yr}^{-1}$ at the North Greenland Ice Core Drilling site (Buchardt and DahlJensen, 2007), although studies have found evidence of melt rates up to $150 \mathrm{~mm} \mathrm{yr}^{-1}$ at the onset of NEGIS (Fahnestock et al., 2001). We consider our assumed melt rate to represent the lower end of the possible melt rates. This assumption is based on a rough estimate of energy available for melting the basal ice; we use the sliding coefficient found in the section above to calculate the basal velocity $u_{\mathrm{b}}=u_{\mathrm{s}}$ and the frictional heat $E=u_{\mathrm{b}} \tau_{\mathrm{b}}$. Assuming that the ice is at pressure melting point and that all energy generated by the friction between ice and bed is used to melt ice (i.e. we disregard dissipation of heat), we get an upper value of possible melt rates. This returns melt rates of between 0 and $0.1 \mathrm{~m} \mathrm{yr}^{-1}$ in areas of intermediate flow (20-100 $\mathrm{m} \mathrm{yr}^{-1}$ ) and upwards of $1 \mathrm{~m} \mathrm{yr}^{-1}$ in the fastest-flowing areas. Figure 5a shows the flux of subglacial water using this upper limit estimate. Note how the subglacial water is routed along the shear margins 

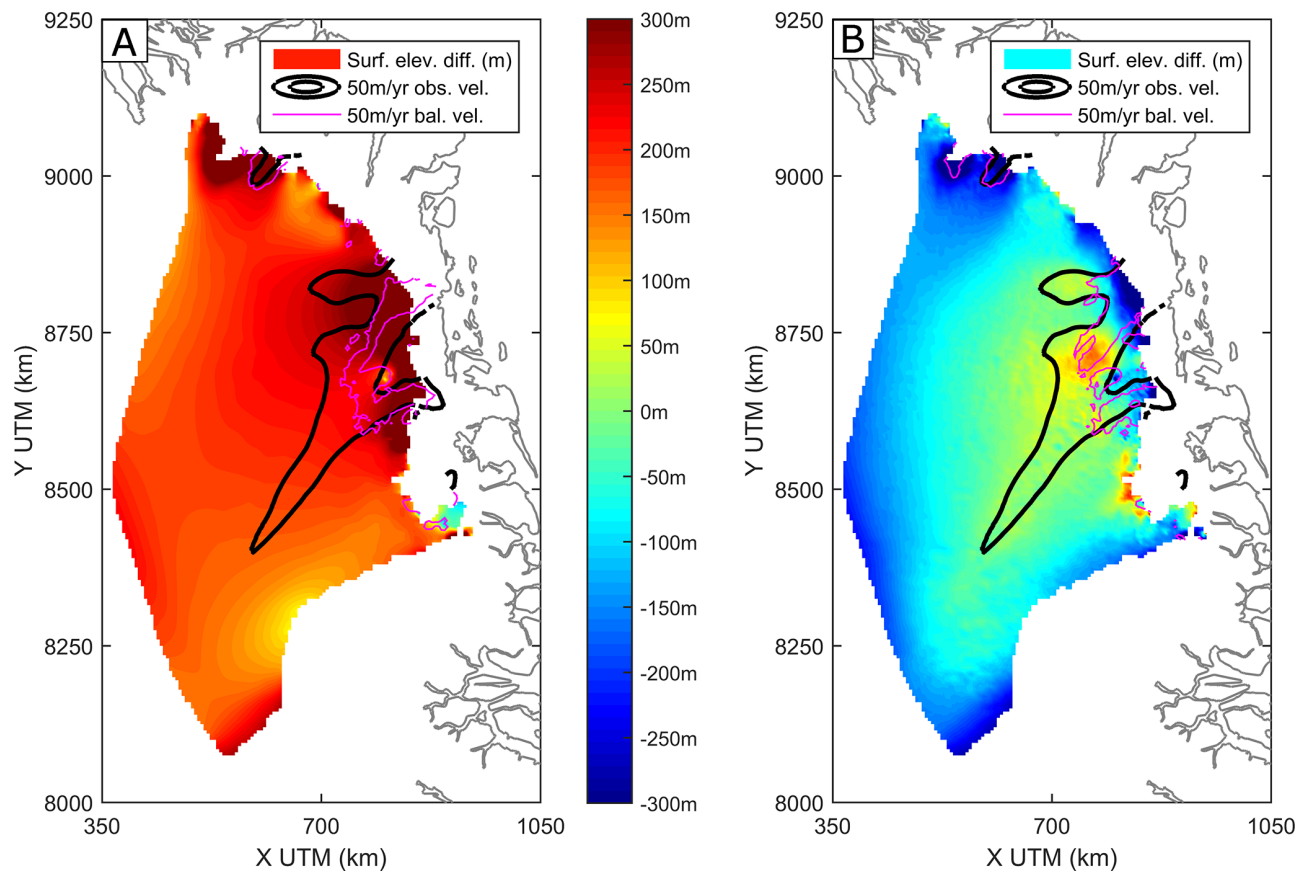

Figure 4. (a) Difference in surface elevation between the ice-sheet at the end of the spin-up run and present-day topography. (b) Difference in surface elevation between the ice-sheet at the end of the model run and present-day topography. The contour for the observed $50 \mathrm{~m} \mathrm{yr}^{-1}$

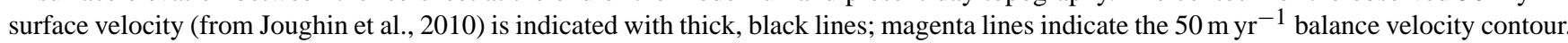
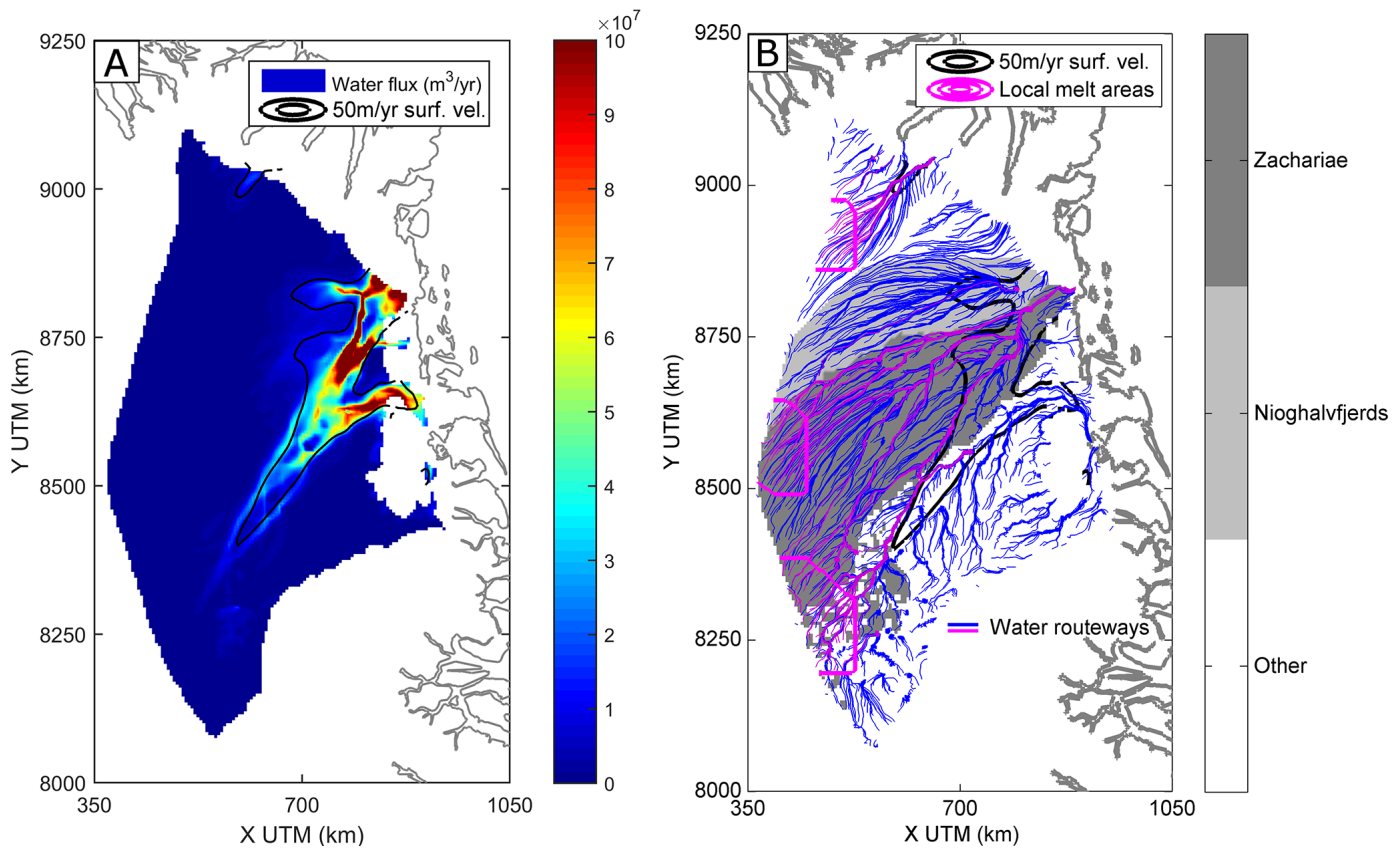

Figure 5. (a) Subglacial water flux for upper values of basal melt rates. (b) Water routeways for the present-day topography; the background colours indicate which outlet the subglacial water is draining into. The magenta contours indicate the areas of localised basal melt from the study by Oswald and Gogineni (2008). The contour for the $50 \mathrm{~m} \mathrm{yr}^{-1}$ surface velocity (from Joughin et al., 2010) is indicated with thick, black lines. 

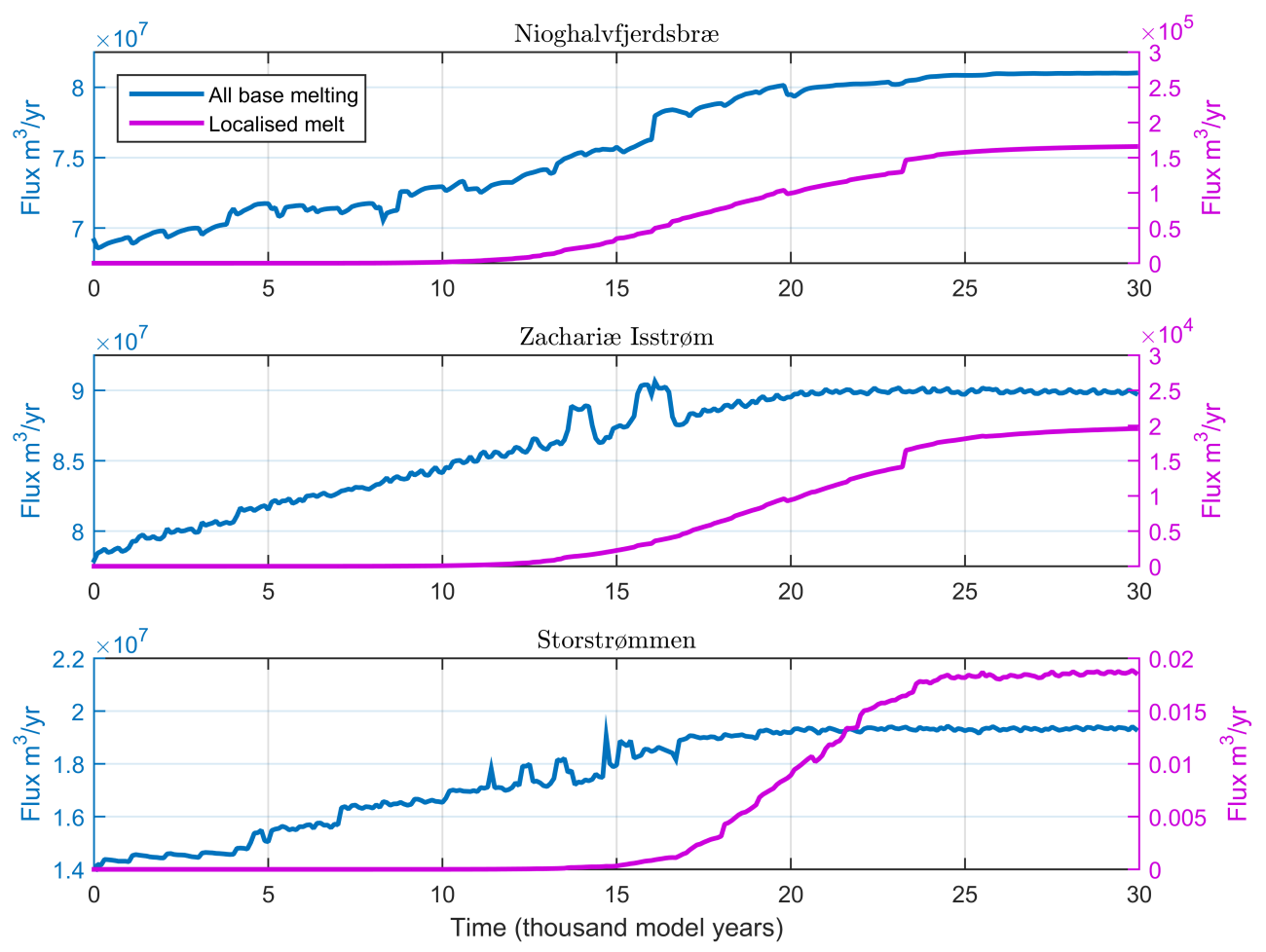

Figure 6. Change in subglacial water outflux at the three main outlets of NEGIS during the $30 \mathrm{kyr}$ model run. The blue lines indicate the changes if the entire basin is at melting point and contributing to the outflux, while the magenta lines are the outflux if only certain local areas are melting.

in agreement with observations from the field (Christianson et al., 2014).

Figure 5 shows the routeways that the subglacial water follows based on present-day surface topography (Bamber et al., 2013a). It is evident that some parts of the basin have a drainage pattern resembling a "parallel" drainage system (e.g. the northern margin of NEGIS) where the water follows almost straight lines, indicating steep gradients in the hydropotential. In contrast, other parts of the basin have a more dendritic structure with multiple tributaries. Here the hydropotential has less steep slopes and the resulting drainage pattern is therefore less constrained. From the figure it can also be seen that presently a large part of the subglacial water is exiting at Zachariae Ice Stream (dark grey), while less water feeds into Nioghalvfjerdsbrae (light grey). Further, if only localised areas are contributing with subglacial water (as identified by radio-echo sounding Oswald and Gogineni, 2008), very little water is presently exiting into Nioghalvfjerdsfjord.

Figure 6 shows the change in outflux over time for the three major glacier outlets of NEGIS, calculated using a routing scheme (as described above). Please note that in the following discussion of variations in the flux over time the constant basal melt rate of $5 \mathrm{~mm} \mathrm{yr}^{-1}$ was used. We set up three flux gates at the glacier outlets close to the margin such that all subglacial water that passes through the flux gates con- tinues towards the margin. The figure shows the total volume of water that passes through a given flux gate. We have further assumed that changes in water transport are instantaneous compared to the timescale of ice flow.

Overall, the water outflow shows large variations on timescales ranging from decades to millennia. This is in agreement with previous studies, which have also found a potential for changes in drainage pattern (Livingstone et al., 2013; Christianson et al., 2014).

As the basal sliding increases with time, the outflux of subglacial water increases at the margins. This happens both in the scenario where the entire basin is assumed to be melting and in the scenario where only the localised melt areas in the interior are supplying basal meltwater. At the end of the spin-up run most of the subglacial water generated along the ice divide flows towards the west. This is a consequence of the $10 \mathrm{~km}$ resolution model generally predicting lower surface elevation than present day, leading to a surface sloping towards the west. This implies that at the end of the spin-up run the basin boundary has migrated inwards and part of the ice is now flowing out of the model domain towards the west. As the sliding coefficient is increased, the ice stream forms and the surface slope now allows more water to flow eastwards, thus increasing the outflux of subglacial water at the margins. 

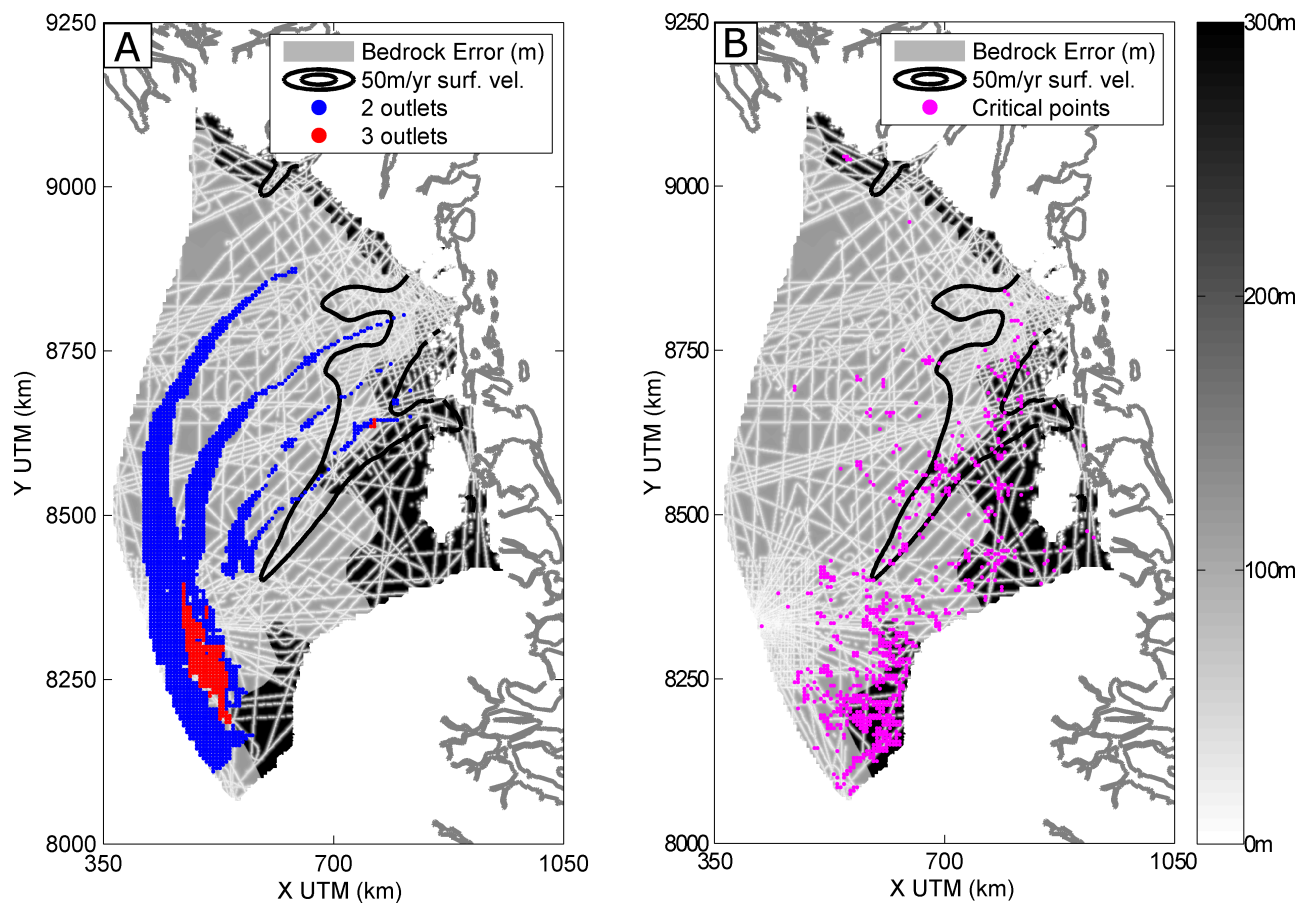

Figure 7. The error associated with the bedrock topography from Bamber et al. (2013a) is in grey. (a) coloured dots indicate grid cells where the subglacial water routeways change between two (blue dots) or three (red dots) outlets. The contour for the $50 \mathrm{~m} \mathrm{yr}^{-1}$ surface velocity (from Joughin et al., 2010) is indicated with thick, black lines. (b) magenta dots indicate grid cells where the bed slope is equally important to or more important than the surface slope in determining the direction of the subglacial water.

After 20 kyr the basal conditions are kept constant and the ice flow is allowed to adjust without forcings, and after a few thousand years the ice-flow model shows surface elevation changes of the order of $10^{-1} \mathrm{~m} \mathrm{yr}^{-1}$ or less. We interpret this as a sign that the model is approaching steady state. However, even after several thousands of years with no external forcing the subglacial water outflux continues to fluctuate. This highlights the sensitivity of the subglacial system to small changes in surface slope. We emphasise that, while our simple ice-flow model does not capture the complicated ice-flow dynamics of the present day, the subglacial water fluctuations are a result of the drainage basin topography.

We now investigate whether the subglacial water from different grid cells is likely to exit at different glacier outlets. Using time slices of $100 \mathrm{yr}$ over the $30 \mathrm{kyr}$ run, we calculate which fjord the subglacial water from each grid cell exits into. Figure 7 a shows the grid cells where there is a change in outlet destination. For $18 \%$ of grid cells (Fig. 7a, blue dots) the majority of the produced subglacial water fluctuates between two outlets. The dots clearly delineate the subglacial "watersheds" between the different outlets. $2 \%$ of grid cells (Fig. 7a, red dots) fluctuate between three different outlets. Notably, many of the cells that change their final destination are relatively close to the ice divide, upstream of NEGIS. This is also in close proximity to the area of high geothermal heat flux identified by Fahnestock et al. (2001), where basal melting is known to take place.
In the previous section (cf. Eq. 7) we asserted that the surface slope is approximately 10 times more important than the bed slope when determining the water routeways. However, in some areas the bed slope is so steep that the bed topography eventually becomes equally important to or more important than the surface topography. Closer inspection of the topography of the model domain reveals that this is indeed the case in some areas. Magenta dots in Fig. 7b indicate the location of the critical grid cells where the bed slope is equally important to or more important than the surface slope, i.e. where $\frac{\left(\rho_{w}-\rho_{i}\right) \nabla z_{\mathrm{b}}}{\rho_{i} \nabla z_{\mathrm{s}}} \approx 1$. A large number of these critical points are located in the southern part of the model domain, although some are also located in the main part of the ice stream. Figure 7 also shows the error associated with the bed topography data set from Bamber et al. (2013a). This error is due to the fact that for some of the bed topography measurements the surface elevation is not well known (Bamber et al., 2013a). When comparing the bedrock error with the grid cells where the subglacial water is likely to change its final destination, it is clear that very few of these grid cells coincide with areas of large bedrock error, implying that the calculated subglacial water routeways in this region are particularly uncertain. In contrast, a large number of the grid cells that are sensitive to the bedrock slope coincide with areas where the bed topography is associated with large errors, 
implying that the calculated subglacial water routeways in this region are particularly uncertain.

\section{Discussion}

Our simple model experiment highlights some interesting characteristics of the large-scale subglacial drainage pattern of Northeast Greenland. Our results indicate that the outflux of subglacial water may fluctuate for several thousand years even after external forcings have ceased. We also observe that the subglacial water from multiple grid cells exits at different glacier outlets (Fig. 7a) during our $30 \mathrm{kyr}$ model run. Interestingly, we find that the grid cells that are most likely to fluctuate between three different outlets are located close to the ice divide. The water routeways at these cells are primarily controlled by surface slope, implying that changes in surface slope are the determining factor for the direction of the subglacial water. As mentioned in a previous section, the ice geometry at the end of the spin-up run has a basin boundary inward of the area covered by the model domain. This new boundary, however, does not extend as far as the area marked with red points in Fig. 7a. Thus, the points closest to the ice divide change outlets because of this boundary migration, i.e. due to the spin-up surface geometry, but the remaining points change outlet due to the internal dynamics in the model domain. This indicates the possibility for farfield controls on the subglacial water system of NEGIS, and that variations in subglacial water outflux at the outlets of Nioghalvfjerdsbræ, Zachariae Isbræ and Storstrømmen may be caused by changes in surface elevation several hundred kilometres upstream. Thus, observed changes at the margins in, for example, water outflux or ice-flow velocity are not necessarily caused by processes that can be observed within the same spatial and temporal scale as the changes.

In our model run, an increase in basal sliding generally leads to a lowering of the ice surface. We hypothesise that the formation of the ice stream could have happened as a positive feedback effect, where the introduction of subglacial water at the bed (i.e. increase in basal sliding) led to a lowering of surface elevation, leading to more subglacial water being rerouted into the system. This in turn might lead to a further lowering of the surface and thereby more subglacial water. However, since our model does not include feedbacks between the subglacial system and ice flow, we cannot truly determine the formation mechanism. It is worth noting that we do not observe "water piracy" in the sense described by Anandakrishnan and Alley (1997), where neighbouring ice streams slow down or speed up when they exchange subglacial water. We also investigated our results for evidence of "ice piracy", where the increase in ice flux for one ice stream happens at the expense of a neighbouring ice stream (e.g. Pattyn et al., 2005). However, the three glacier outlets all showed increasing ice fluxes, as the ice stream became more pronounced with increased basal sliding. There might be a potential for ice piracy between NEGIS and Hagen Bræ/Academy Glacier in the northern part of the basin, but this outlet glacier is not well resolved at $5 \mathrm{~km}$ grid resolution, and we do not observe evidence of ice piracy in our model results. We would like to stress that the channelling of subglacial water includes processes that are still poorly understood but which may strongly influence the timescales of the changes in ice-flow dynamics. Our model most likely underestimates the timescales over which these processes are taking place since it does not include feedback between the ice-flow dynamics and the subglacial system.

In the ice-flow model the driving stress is assumed equal to the basal shear stress in the direction of flow. Ice streams are commonly modelled using a shallow-shelf approach where the basal shear stress is assumed to be negligible (e.g. MacAyeal, 1989) and sliding is dominating. However, studies have found that in large parts of the NEGIS the basal shear stress is balanced by the driving stress (Joughin et al., 2001). Our assumption is thus applicable for a large part of our model domain, with two notable exceptions. The first exception is the upper part of NEGIS close to the initiation of the ice stream, where side drag from the margins cannot be neglected. Here, the bed most likely only support $60 \%$ of the driving stress. This exception is probably an important contributing factor in explaining why our model does not display a distinct onset of the ice stream. The missing ice-stream onset means that our modelled surface topography is smoother than it would be if the onset existed. The second exception is the "ice plain" (located downstream of the place where part of NEGIS branches out and forms Storstrømmen). In this area, the stresses are dominated by significant side drag (Joughin et al., 2001). This explains why we see a build-up of mass in the central part of the ice stream (Fig. 4b): inclusion of additional stresses probably would lead to more efficient transport of ice across the ice plain. For the ice plain our model assumptions mean an underestimation of ice-flow velocities and the associated timescales over which changes in ice thickness are happening. To summarise, a higher-order ice-flow model would most likely display a faster formation of the NEGIS, as well as steeper gradients in the hydropotential in the region where our modelled surface topography is too smooth. This could impact the modelled change in subglacial water routeways of the grid cells identified in Fig. 7a. It is possible that some of the grid cells located close to the onset of the ice stream are less sensitive to changes in surface slope than predicted in our model. This is because a more pronounced ice-stream topography would cause steeper gradients in the hydropotential and a more constrained subglacial drainage pattern. However, we note that water routeways north of the onset do not currently drain into NEGIS, in spite of the prominent imprint the ice stream makes on the surface (cf. Fig. 5b). This makes us confident that our assessment of the sensitivity of the grid cells north of the onset of NEGIS is correct, i.e. that even for present-day topography with steeper gradients in the hydropotential they can still 
be sensitive to changes in surface slope. The subglacial water routeways originating at the grid cells along the margin of NEGIS are probably less sensitive to changes in surface slope.

In our study, we have assumed that the subglacial water is transported to the glacier margin and does not form subglacial lakes. Pattyn (2008) suggested that steep surface slopes in combination with warmer, thinner ice in the interior of GrIS (compared to Antarctica) inhibit the formation of subglacial lakes. Indeed, at present only one study has found direct evidence of subglacial lakes in Greenland (Palmer et al., 2013). In our calculations of present-day Greenland water routeways (Fig. 5b) the water routeways can be seen to pool together in the southeastern part of the drainage basin, indicating the possibility of subglacial lakes. Their positions correspond largely to areas identified by Livingstone et al. (2013) as potential lake locations. However, the areas likely to contain subglacial lakes in our study coincide not only with areas where the bed slope is equally or more important than the surface slope, but also with areas where the error in bed rock topography is upwards of $300 \mathrm{~m}$ (Fig. 7b). Thus, these subglacial lake locations are at best uncertain considering the large bedrock error in the region. However, the areas likely to contain subglacial lakes in our study coincide not only with areas where the bed slope is equally important to or more important than the surface slope, but also with areas where the error in bedrock topography is upwards of $300 \mathrm{~m}$ (Fig. 7b). Thus, these subglacial lake locations are at best uncertain considering the large bedrock error in the region.

Previous studies have found that NEGIS has the potential to experience rapid shifts in ice dynamics (Christianson et al., 2014). While the step-wise change in sliding coefficient that we apply to induce surface elevation changes is an unlikely scenario, a change in surface elevation could be triggered by a number of processes. For example, studies by Alley and Whillans (1984) and Williams et al. (2012) have found that processes happening over centuries to millennia at the front of ice streams may trigger changes in slope and thickness hundreds of kilometres inland from the margin. Thus, a steady increase in calving rate over the past few hundred years caused by, for example, warming sea surface temperatures will propagate upstream and could eventually lead to a rerouting of the subglacial water, without any observable catastrophic or sudden change in forcing. This implies that if a retreat/advance happened slowly enough for the perturbation to propagate far upstream, we could still be observing the response of the subglacial system to the changes in surface elevation.

It is very plausible that retreats and advances have occurred in the past along the margin of Northeast Greenland. For example, geological evidence suggests that $7.7 \mathrm{kyr}$ before present the margin of Nioghalvfjerdsbræen was $80 \mathrm{~km}$ upstream from its present location (Bennike and Björck, 2002). It is also known that glaciers in other parts of Greenland (e.g. Bjørk et al., 2012) advanced during the Little Ice
Age. These changes must have influenced ice thicknesses in the drainage basin, but the extent of the impact is unknown. Furthermore, the duration of the margin changes are also unknown, and therefore how far the surface fluctuations propagated upstream cannot be easily assessed. However, events such as these could have led to a change in surface slope and, based on our results, caused a corresponding change in subglacial water routeways. This could ultimately have caused a change in ice-flow velocities and ice-stream configuration. Since these events may take centuries to millennia to propagate upstream, it also seems likely that the surface slope is constantly modified by fluctuations from processes at the margin. It is therefore likely that the subglacial system is constantly changing in response to these fluctuations and likely never in a steady state. It further indicates that changes in the subglacial water routeways are an intrinsic part of the drainage basin dynamics, where the subglacial system is constantly transitioning between different configurations of the subglacial water network. Thus, current observations of increase/decrease in velocity could be a delayed effect from changes taking place before the observational period, working their influence on critical points upstream of the glacier front.

The latest bed topography data show that some ice streams in Greenland are constrained by deep troughs (e.g. Jakobshavn Isbræ; Gogineni et al., 2014), while other Greenlandic ice streams are not strongly controlled by bed topography (Bamber et al., 2013a). We therefore hypothesise that other drainage basins in Greenland also might experience subglacial rerouting of water and corresponding fluctuations in ice-flow velocities. The model presented here is a tool that could be applied to other parts of GrIS, and thus the sensitivity of the subglacial drainage pattern in different drainage basins could be assessed. Places of interest include the basin containing the Petermann and Humboldt glaciers, and the glaciers on the northwest coast. Both of these areas could have potential for subglacial water rerouting. For example, studies have found that in Northern Greenland changes in the subglacial waterways are likely to have taken place during the last glacial maximum (cf. Bamber et al., 2013b). The method outlined in this paper could be used to investigate the change in subglacial drainage patterns as the ice sheet retreated and thinned after the last glacial maximum to its present-day state. Alternatively, the model could be applied to the whole of the ice sheet; during glacial times, GrIS most likely extended out onto the continental shelf and formed an ice bridge with the Laurentide Ice Sheet (e.g. Dyke, 2004). The break up of this bridge most likely impacted the surface topography of the ice sheet and therefore also the subglacial water routeways. Finally, the applicability of the model might be improved with the addition of a shallow-shelf mode (e.g. MacAyeal et al., 1996) in order to better capture the ice-stream dynamics. 


\section{Conclusions}

The dynamics of the Northeast Greenland drainage basin have received increased attention in recent years. Here, we investigate the response of the subglacial drainage pattern to changes in surface elevation for Northeast Greenland using a simple 2-D map-plane ice-flow model. We use observed surface velocities to invert for the basal sliding coefficient $k_{\mathrm{S}}$ and then run the ice-flow model forward in time with incremental increases in the basal sliding. We find that the subglacial water routeways readily change in response to fluctuations in surface slope. The fluctuations continue for millennia after the forcing of the basal conditions has stopped. The results further show that areas close to the ice divide, upstream of the fast-flowing NEGIS, may fluctuate between several glacier outlets, indicating the potential for far-field controls on water outflux at the margins. Since changes at the margin may propagate upstream and modify surface slopes on multiple timescales, our study highlights how fluctuations of the subglacial system are an intrinsic part of the ice-flow dynamics of Northeast Greenland due to the sensitivity to changes in surface slope. Thus, changes presently observed at the margin could be a response to upstream changes induced by processes that occurred centuries to millennia ago. We strongly encourage future work to include these processes to obtain better controls on the timescales of the system. 


\section{Appendix A: Inverting for the deformation and sliding coefficients}

We obtain our estimates of the deformational coefficient $k_{\mathrm{d}}$ and the sliding coefficient $k_{\mathrm{s}}$ with a simple inverse method using a Monte Carlo scheme (e.g. Tarantola, 2005). In the model we have an observed data set $d^{\text {obs }}$, consisting of the velocity field from Joughin et al. (2010), and a modelled data set $d(m)$, with the velocities calculated using model parameters $m$. The misfit between the observed and the calculated data set is assessed via the misfit function:

$S(m)=\frac{1}{2} \sum_{i} \frac{\left(d_{i}^{\mathrm{obs}}-d_{i}\right)^{2}}{s_{i}^{2}}$,

where $i$ runs over all the grid cells in the model domain. The model explores the parameter space (the likely range of $m$ ) with a random walk. Each result from the random walk is either accepted or rejected according to the Metropolis criterion:

$P=\min \left(1, \frac{L\left(m_{\text {cur }}\right)}{L\left(m_{\text {test }}\right)}\right)$,

where $m_{\text {cur }}$ is the most recently accepted model, $m_{\text {test }}$ is the model being tested and $L$ is the likelihood function given as

$L(m)=c \exp (-S(m))$.

Here $c$ is a normalisation constant that we set equal to 1 .
In our study we first find the deformational coefficient $k_{\mathrm{d}}$ using a pre-defined likely range of $k_{\mathrm{d}}$ values. The coefficient is assumed to be constant for the entire basin, and it is used as input to calculate $\bar{u}_{\mathrm{d}}$. The misfit between the observed and calculated velocities is assessed using the misfit function described above. Furthermore, a weighting mask is applied such that the misfit in low-velocity areas is 4 times more important for the sum of the misfits than the intermediatevelocity areas, while high-velocity areas are disregarded in the fitting analysis. Once the misfits reach a steady value, the algorithm is halted and the resulting value of $k_{\mathrm{d}}$ is accepted.

Next, we use the $k_{\mathrm{d}}$ value to run our simple model of calculated velocities $\bar{u}=\bar{u}_{\mathrm{d}}+u_{\mathrm{s}}$, where our model parameter now is $k_{\mathrm{s}}$. Again, using a pre-defined likely range of $k_{\mathrm{S}}$ values, but this time allowing $k_{\mathrm{s}}$ to vary for each grid cell. Now the weighting scheme is reversed and the fast-flow areas become 4 times more important than the intermediate-velocity areas, while the misfit in the slow-flow areas is disregarded. Again, the resulting value of $k_{\mathrm{S}}$ is accepted when the misfits no longer improve. 
Acknowledgements. N. B. Karlsson is supported by European Research Council grant no. 246815 "Water Under the Ice". The Centre for Ice and Climate is funded by the Danish National Research Foundation. We are grateful for the helpful and thorough comments from two anonymous reviewers and the editor F. Pattyn.

Edited by: F. Pattyn

\section{References}

Alley, R. and Whillans, I. M.: Response of the East Antarctica ice sheet to sea-level rise, J. Geophys. Res., 89, 6487-6493, 1984.

Alley, R. B., Blankenship, D. D., Bentley, C., and S. T., Rooney: Deformation of till beneath Ice Stream B, West Antarctica, Nature, 322, 57-59, 1986.

Anandakrishnan, S. and Alley, R. B.: Stagnation of ice stream C, West Antarctica by water piracy, Geophys. Res. Lett., 24, 265268, 1997.

Bamber, J. L., Griggs, J. A., Hurkmans, R. T. W. L., Dowdeswell, J. A., Gogineni, S. P., Howat, I., Mouginot, J., Paden, J., Palmer, S., Rignot, E., and Steinhage, D.: A new bed elevation dataset for Greenland, The Cryosphere, 7, 499-510, doi:10.5194/tc-7499-2013, 2013a.

Bamber, J. L., Siegert, M. J., Griggs, J. A., Marshall, S. J., and Spada, G.: Paleofluvial Mega-Canyon Beneath the Central Greenland Ice Sheet, Science, 341, 997-999, 2013 b.

Bennike, O. and Björck, S.: Chronology of the last recession of the Greenland Ice Sheet, J. Quaternary Sci., 17, 211-219, 2002.

Bevan, S. L., Luckman, A. J., and Murray, T.: Glacier dynamics over the last quarter of a century at Helheim, Kangerdlugssuaq and 14 other major Greenland outlet glaciers, The Cryosphere, 6, 923-937, doi:10.5194/tc-6-923-2012, 2012.

Bindschadler, R.: The importance of pressurized subglacial water in separation and sliding at the glacier bed., J. Glaciol., 29, 3-19, 1983.

Bjørk, A. A., Kjær, K. H., Korsgaard, N. J., Khan, S. A., Kjeldsen, K. K., Andresen, C. S., Box, J. E., Larsen, N. K., and Funder, S.: An aerial view of 80 years of climate-related glacier fluctuations in southeast Greenland, Nature Geosci., 5, 427-432, 2012.

Bolch, T., Sandberg Sørensen, L., Simonsen, S. B., Mölg, N., Machguth, H., Rastner, P., and Paul, F.: Mass loss of Greenland's glaciers and ice caps 2003-2008 revealed from ICESat laser altimetry data, Geophys. Res. Lett., 40, 875-881, 2013.

Bougamont, M., Price, S., Christoffersen, P., and Payne, a. J.: Dynamic patterns of ice stream flow in a 3-D higher-order ice sheet model with plastic bed and simplified hydrology, J. Geophys. Res., 116, F04018, doi:10.1029/2011JF002025, 2011.

Buchardt, S. L. and Dahl-Jensen, D.: Estimating the basal melt rate at NorthGRIP using a Monte Carlo technique, Ann. Glaciol., 45, 137-142, 2007.

Budd, W. F. and Warner, R. C.: A computer scheme for rapid calculations of balance-flux distributions, Ann. Glaciol., 23, 21-27, 1996.

Budd, W. F., Keage, P. L., and Blundy, N. A.: Empirical studies of ice sliding, J. Glaciol., 23, 157-170, 1979.

Calov, R., Robinson, A., Perrette, M., and Ganopolski, A.: Simulating the Greenland ice sheet under present-day and palaeo constraints including a new discharge parameterization, The Cryosphere, 9, 179-196, doi:10.5194/tc-9-179-2015, 2015.

Christianson, K., Peters, L. E., Alley, R. B., Anandakrishnan, S., Jacobel, R. W., Riverman, K. L., Muto, A., and Keisling, B. a.: Dilatant till facilitates ice-stream flow in northeast Greenland, Earth Planet. Sci. Lett., 401, 57-69, 2014.

Clarke, G. K.: Subglacial Processes, Ann. Rev. Earth Planet. Sci., 33, 247-276, 2005.

Cuffey, K. M. and Paterson, W. S. B.: The Physics of Glaciers, Butterworth-Heinemann, 2010.

Dahl-Jensen, D., Gundestrup, N., Gogineni, S. P., and Miller, H.: Basalmelt at NorthGRIP modeled from borehole, ice-core and radio-echo sounder observations, Ann. Glaciol., 37, 207-212, 2003.

de Fleurian, B., Gagliardini, O., Zwinger, T., Durand, G., Le Meur, E., Mair, D., and Råback, P.: A double continuum hydrological model for glacier applications, The Cryosphere, 8, 137-153, doi:10.5194/tc-8-137-2014, 2014.

Dyke, A. S.: Quaternary Glaciations: Extent and Chronology, vol. 2, pp. Elsevier, 373-424, 2004.

Ettema, J., van den Broeke, M. R., van Meijgaard, E., van de Berg, W. J., Bamber, J. L., Box, J. E., and Bales, R. C.: Higher surface mass balance of the Greenland ice sheet revealed by high-resolution climate modeling, Geophys. Res. Lett., 36, doi:10.1029/2009GL038110, 2009.

Fahnestock, M., Bindschadler, R., Kwok, R., and Jezek, K.: Greenland Ice Sheet Surface Properties and Ice Dynamics from ERS-1 SAR Imagery, Science, 262, 1530-1534, 1993.

Fahnestock, M., Abdalati, W., Joughin, I., Brozena, J., and Gogineni, P.: High Geothermal Heat Flow, Basal Melt, and the Origin of Rapid Ice Flow in Central Greenland, Science, 294, 23382342, 2001.

Gogineni, S., Tammana, D., Braaten, D., Leuschen, C., Akins, T., Legarsky, J., Kanagaratnam, P., Stiles, J., Allen, C., and Jezek, K.: Coherent radar ice thickness measurements over the Greenland ice sheet, J. Geophys. Res., 106, 33761-33772, 2001.

Gogineni, S., Yan, J.-B., Paden, J. D., Leuschen, C., Li, J., Rodriguez-Morales, F., Braaten, D., Purdon, K., Wang, Z., Liu, W., and Gauch, J.: Bed topography of Jakobshavn Isbræ, Greenland, and Byrd Glacier, Antarctica, J. Glaciol., 60, 813-833, 2014.

Greve, R.: Relation of measured basal temperatures and the spatial distribution of the geothermal heat flux for the Greenland ice sheet, Ann. Glaciol., 42, 424-432, 2005.

Greve, R. and Hutter, K.: Poly thermal three-dimensional modelling of the Greenland ice sheet with varied geothermal heat flux, Ann. Glaciol., 21, 8-12, 1995.

Gulley, J., Benn, D., Screaton, E., and Martin, J.: Mechanisms of englacial conduit formation and their implications for subglacial recharge, Quaternary Sci. Rev., 28, 1984-1999, 2009.

Hanna, E., Navarro, F. J., Pattyn, F., Domingues, C. M., Fettweis, X., Ivins, E. R., Nicholls, R. J., Ritz, C., Smith, B., Tulaczyk, S., Whitehouse, P. L., and Zwally, H. J.: Ice-sheet mass balance and climate change., Nature, 498, 52-59, 2013.

Iverson, N. R. and Petersen, B. B.: A new laboratory device for study of subglacial processes: first results on ice-bed separation during sliding, J. Glaciol., 57, 1135-1146, 2011. 
Joughin, I., Fahnestock, M., MacAyeal, D., Bamber, J. L., and Gogineni, P.: Observation and analysis of ice flow in the largest Greenland ice stream, J. Geophys. Res., 106, 34021-34034, 2001.

Joughin, I., Smith, B. E., Howat, I. M., Scambos, T., and Moon, T.: Greenland flow variability from ice-sheet-wide velocity mapping, J. Glaciol., 56, 415-430, 2010.

Keisling, B. A., Christianson, K. A., Alley, R. B., Peters, L. E., Christian, J. E. M., Anandakrishnan, S., Riverman, K. L., Muto, A., and Jacobel, R. W.: Basal conditions and ice dynamics inferred from radar-derived internal stratigraphy of the northeast Greenland ice stream, Ann. Glaciol., 55, 127-137, 2014.

Khan, S. A., Kjaer, K. H., Bevis, M., Bamber, J. L., Wahr, J., Kjeldsen, K. K., Bjork, A. A., Korsgaard, N. J., Stearns, L. A., van den Broeke, M. R., Liu, L., Larsen, N. K., and Muresan, I. S.: Sustained mass loss of the northeast Greenland ice sheet triggered by regional warming, Nature Climate Change, 4, 292-299, 2014.

Larour, E., Utke, J., Csatho, B., Schenk, A., Seroussi, H., Morlighem, M., Rignot, E., Schlegel, N., and Khazendar, A.: Inferred basal friction and surface mass balance of the Northeast Greenland Ice Stream using data assimilation of ICESat (Ice Cloud and land Elevation Satellite) surface altimetry and ISSM (Ice Sheet System Model), The Cryosphere, 8, 2335-2351, doi:10.5194/tc-8-2335-2014, 2014.

Le Brocq, A. M., Payne, A. J., and Siegert, M. J.: West Antarctic balance calculations: Impact of flux-routing algorithm, smoothing algorithm and topography, Compu. Geosci., 32, 1780-1795, 2006.

Livingstone, S. J., Clark, C. D., Woodward, J., and Kingslake, J.: Potential subglacial lake locations and meltwater drainage pathways beneath the Antarctic and Greenland ice sheets, The Cryosphere, 7, 1721-1740, doi:10.5194/tc-7-1721-2013, 2013.

MacAyeal, D. R.: Large-Scale Ice Flow Over a Viscous Basal Sediment: Theory and Application to Ice Stream B, Antarctica, J. Geophys. Res., 94, 4071-4087, 1989.

MacAyeal, D. R., Hulbe, C. L., Huybrechts, P., Rommelaere, V., Determann, J., and Ritz, C.: An ice-shelf model test based on the Ross ice shelf, Ann. Glaciol., 23, 46-51, 1996.

Oerlemans, J.: Glaciers \& Climate Change, Taylor \& Francis, 1st Edn., 2001.

Oswald, G. and Gogineni, S.: Mapping Basal Melt Under the Northern Greenland Ice Sheet, IEEE Trans. Geosci. Remote Sens., 50, 585-592, 2012.

Oswald, G. K. A. and Gogineni, S. P.: Recovery of subglacial water extent from Greenland radar survey data, J. Glaciol., 54, 94-106, 2008.

Palmer, S. J., Dowdeswell, J. A., Christoffersen, P., Young, D. A., Blankenship, D. D., Greenbaum, J. S., Benham, T., Bamber, J., and Siegert, M. J.: Greenland subglacial lakes detected by radar, Geophys. Res. Lett., 40, 6154-6159, 2013.

Pattyn, F.: Investigating the stability of subglacial lakes with a full Stokes ice-sheet model, J. Glaciol., 45, 353-361, 2008.
Pattyn, F., de Brabander, S., and Huyghe, A.: Basal and thermal control mechanisms of the Ragnhild glaciers, East Antarctica, Ann. Glaciol., 40, 225-231, 2005.

Rignot, E. and Kanagaratnam, P.: Changes in the velocity structure of the Greenland Ice Sheet., Science, 311, 986-90, 2006.

Schlegel, N.-J., Larour, E., Seroussi, H., Morlighem, M., and Box, J. E.: Decadal-scale sensitivity of Northeast Greenland ice flow to errors in surface mass balance using ISSM, J. Geophys. Res., 118, 667-680, 2013.

Schoof, C.: Ice-sheet acceleration driven by melt supply variability, Nature, 438, 803-806, 2010.

Seroussi, H., Morlighem, M., Rignot, E., Khazendar, a., Larour, E., and Mouginot, J.: Dependence of century-scale projections of the Greenland ice sheet on its thermal regime, J. Glaciol., 59, 10241034, 2013.

Shreve, R. L.: Movement of Water in Glaciers, J. Glaciol., 11, 205214, 1972.

Tarantola, A.: Inverse Problem Theory and Methods for Model Parameter Estimation, SIAM Society for Industrial and Applied Mathematics, 2005

van den Broeke, M., Bamber, J., Ettema, J., Rignot, E., Schrama, E., van de Berg, W. J., van Meijgaard, E., Velicogna, I., and Wouters, B.: Partitioning Recent Greenland Mass Loss, Science, 326, 984 986, 2009.

Vaughan, D., Comiso, J., Allison, I., Carrasco, J., Kaser, G., Kwok, R., Mote, P., Murray, T., Paul, F., Ren, J., Rignot, E., Solomina, O., Steffen, K., and Zhang, T.: Climate Change 2013: The Physical Science Basis. Contribution of Working Group I to the Fifth Assessment Report of the Intergovernmental Panel on Climate Change, chap. Observations: Cryosphere, pp. 317-382, Cambridge University Press, Cambridge, United Kingdom and New York, NY, USA, 2013.

Vaughan, D. G., Corr, H. F., Smith, A. M., Pritchard, H. D., and Shepherd, A.: Flow-switching and water piracy between Rutford Ice Stream and Carlson Inlet, West Antarctica, J. Glaciol., 54, 41-48, 2008.

Weertman, J.: On the sliding of glaciers, J. Glaciol., 3, 33-38, 1957.

Williams, C. R., Hindmarsh, R. C. A., and Arthern, R. J.: Frequency response of ice streams, Proc. Roy. Soc. A, 468, 3285-3310, 2012.

Winsborrow, M. C., Clark, C. D., and Stokes, C. R.: What controls the location of ice streams?, Earth-Sci. Rev., 103, 45-59, 2010.

Wright, A. P., Siegert, M. J., Brocq, A. M. L., and Gore, D. B.: High sensitivity of subglacial hydrological pathways in Antarctica to small ice-sheet changes, Geophys. Res. Lett., 35, L17504, doi:10.1029/2008GL034937, 2008.

Zwally, H. J., Abdalati, W., Herring, T., Larson, K., Saba, J., and Steffen, K.: Surface melt-induced acceleration of Greenland icesheet flow, Science, 297, 218-222, 2002. 